\title{
Analysis of bed use performance of pediatrics clinics in Turkey
}

\section{Türkiye'de pediatri kliniklerinin yatak kullanım performansının analizi}

\author{
(1) Arzu Yiğit ${ }^{1}$ \\ Department of Health Management, Süleyman Demirel University Faculty of Economics and Administrative Sciences Isparta, Turkey
}

\begin{abstract}
Introduction: One of the most important sources of hospitals is patient beds. About $14 \%$ of the total patients in Turkey are allocated clinical pediatrics. Efficient and efficient use of the allocated beds significantly affects hospital performance. The study is aimed to analyze pediatric clinics bed use performance by using Pabon Lasso Model (PLM) in Turkey.

Methods: Pabon Lasso Model was used to determine the bed use performance levels of pediatric clinics. In this model, hospital performance indicators are used as variables; bed occupancy rate (BOR), bed turnover rate (BTR) and average length of stay (ALS). Research data were obtained from the Statistical Report of Public Hospitals Unions. Data were analyzed using MS Excel, SPSS 22 software and Pabon Lasso graph.

Results: According to the results obtained, bed performance indicators of pediatric clinics which BOR, BRT and ALS were found to be on average 46.2, 5.7 and 41.8, respectively. According to the model, pediatric surgery and urology and pediatric health and diseases clinics have the highest bed performance, while the most inefficient clinics are pediatric metabolic diseases, pediatric rheumatology and pediatric neurology. In the study, $38 \%$ of pediatric clinics are in the third most fertile region, while $44 \%$ of the first inefficient region is located.

Discussion and Conclusion: Hospitals are the most important element of a health system. Most of the resources allocated to the health sector are allocated to hospitals. Hence, we can say that hospitals are the most basic and most expensive component of health systems. The bed efficiency of hospitals has a significant impact on health system performance. The bed occupancy rate of the pediatric clinic was determined to be $46 \%$ in Turkey. This rate is lower than the average general hospital in Turkey. Therefore, in order for pediatric clinics to provide quality and cost-effective health care, bed performance should be evaluated regularly.
\end{abstract}

Keywords: Hospital; Pabon Lasso Model; pediatric clinics; performance.
Özet

Amaç: Hastanelerin en önemli kaynaklarından birisi hasta yataklarıdır. Türkiye'de toplam hasta yatağının yaklaşık \%14'ü pediatri kliniklerine tahsis edilmektedir. Tahsis edilen bu yatakların etkin ve verimli kullanılması hastane performansını önemli ölçüde etkilemektedir. Bu araştırmanın amacı, Türkiye'de pediatri kliniklerinin yatak kullanım performansını Pabon Lasso Modeli (PLM) ile analiz etmektir.

Gereç ve Yöntem: Araştırmada pediatri kliniklerinin yatak kullanım performans düzeylerini tespit edebilmek için Pabon Lasso Modeli (PLM) kullanılmıştır. PLM'nde değişken olarak hastane performans göstergeleri olan; yatak doluluk oranı (YDO), yatak devir hızı (YDH) ve ortalama kalış süresi (OKS) alınmıştır. Araştırma verileri Kamu Hastane Birlikleri İstatistik Raporundan temin edilmiştir. Verilerin analizinde MS Excel, SPSS 22 software and Pabon Lasso grafiği kullanılmıştır.

Bulgular: Araştırma sonuçlara göre, yatak performans göstergeleri olan YDO, OKS ve YDH'nın pediatrik kliniklerde ortalaması sırasıyla 46,2, 5,7 ve 41,8 olduğu tespit edilmiştir. Modele göre yatak performansı en yüksek klinikler pediatrik cerrahi ve üroloji ile çocuk sağlığı ve hastalıkları iken en verimsiz klinikler ise çocuk metabolizma hastalıkları, çocuk romatolojisi ve çocuk nörolojisi olduğu tespit edilmiştir. Araştırmada pediatrik kliniklerin \%38'i en verimli bölge olan üçüncü bölgede yer alır iken en verimsiz bölge olan birinci bölgede pediatrik kliniklerin $\% 44$ 'ü yer almaktadır.

Sonuç: Hastaneler bir sağlık sisteminin en önemli unsudur. Sağlık sektörüne tahsis edilen kaynakların çoğu hastanelere tahsis edilmektedir. Dolayısıyla, hastanelerin sağlık sistemlerinin en temel ve en pahalı bileşeni olduğunu söyleyebiliriz. Hastanelerin yatak verimliliğinin sağlık sistemi performansı üzerinde önemli bir etkisi vardır. Türkiye'de pediatrik kliniklerin yatak doluluk oranı \%46 olarak tespit edilmiştir. Bu oran Türkiye'deki genel hastane ortalamasından oldukça düşüktür. Bu nedenle, pediatrik kliniklerin kaliteli ve düşük maliyetli sağlık hizmeti sunabilmesi için yatak performansı düzenli olarak değerlendirilmelidir. Anahtar Sözcükler: Hastane; Pabon Lasso Modeli; pediatrik klinikler; performans. 
$\mathrm{H}_{\mathrm{t}}$ ospitals are the most important element of a health system. Most of the resources allocated to the health sector are allocated to hospitals. Hence, we can say that hospitals are the most basic and most expensive component of health systems. This makes it inevitable to improve the overall performance levels of hospitals. There was no increase in the price of health services in Turkey for 12 years. However, there has been a significant increase in healthcare service costs. In recent years, both the reimbursement system and the health policies implemented and the poor performance of hospitals have affected the financial sustainability of hospitals. ${ }^{[1]}$ One of the most important sources of hospitals is patient beds. About $14 \%$ of the total patients. ${ }^{[2]}$ in Turkey are allocated clinical pediatrics. Hence efficient and efficient use of the allocated beds significantly affects hospital performance.

There are many different models for evaluating the performance of hospitals. Many of these models work with mathematical formulation. ${ }^{[3,4]}$ One of the most important and useful models for evaluating the bed performance of hospitals is the PLM. This model is a frequently used performance tool for evaluating bed performance in hospitals. PLM is a graphical model that determines the relative performance by using the bed occupancy rate (BOR), bed turnover rate (BTR) and average length of stay (ALS) indicators. ${ }^{[5]}$ Efficiency and performance show how well an organization uses existing resources. ${ }^{[6]}$ Performance evaluation in hospitals is a process related to the evaluation, measurement and implementation of performance in a certain period of time. ${ }^{[7]}$ Performance evaluation provides useful information to hospital managers on issues related to the evaluation and monitoring of current situation and activities. Capacity utilization level in the evaluation of performance and cost monitoring in hospitals provides information to hospital managers. Capacity utilization rate is one of the main performance indicators in hospitals. ${ }^{[8]}$

PLM developed by Pabón Lasso (1986), is a graphical technique that uses BOR, BTR and ALS indicators to measure relative hospital performance. ${ }^{[9]}$ This model is considered to be an alternative method that makes it possible to measure performance with a simple graph and is easier to understand than other performance measurement models. ${ }^{[3]}$ PLM can be used to compare the performance of different hospitals of the same hospital types or different units within the same hospital. ${ }^{[10]}$ Hospital bed performance indicators BOR, BTR and ALS are explained in detail in Table 1. ${ }^{[1]}$
There are four regions in this model where there may be hospitals or clinics (Fig. 1). There are two crossing lines that determine these regions by mean BTR and BOR. In the graphical model, BTO is placed on the vertical and BOR on the horizontal axis. Given a mathematical correlation between these three criteria, a line starting from zero and passing through each point in the graph shows ALS that increases from left to right and continuously from top to bottom. ${ }^{[9,12,13]}$

The main feature of the hospitals or services in the first region is the low bed turnover rate and low bed occupancy rate. In addition, the average length of stay in hospitals or services in this region is too long. The main feature of the hospitals in this region is that the demand is low and they have more beds than necessary. ${ }^{[7]}$ The common feature of hospitals or services in the second region is low bed occupancy, high bed turnover and short length of stay. Clinics that place patients on shortterm supervision or provide daily treatment are located in this region. For example, gynecology, dermatology and eye clinics of hospitals are located in this region. ${ }^{[3]}$ In this model, hospitals and clinics in the third region are the most productive. The most important feature of the third region is that the hospitals and clinics located here have high bed turnover rate and high bed occupancy rate. ${ }^{[14]}$ Hospitals and clinics in the fourth region have low bed turnover rate, high bed occupancy rate and long length of stay. In this region, there are hospitals and clinics with patients with severe chronic illnesses who receive treatment and care services in psychiatry or geriatrics. Average length of stay leads to high patient unit costs. In this region, prolonged average length of stay of patients may cause inefficiency. ${ }^{[11,14]}$

\section{Materials and Method}

The aim of this study was to analyze the bed use performance of pediatric clinics with PLM. The population of the study consists of the pediatric clinics of the hospitals affiliated to the Public Hospitals Institution. This cross-sectional study was conducted in 2017 on the pediatric clinics of hospitals. The scope of the research, sixteen pediatric clinics were taken and no sample was taken in the study. In the study, hospital performance indicators were used as variables; bed occupancy rate, bed turnover rate and average length of stay. Research data were obtained from the Statistical Report of Public Hospitals Unions. ${ }^{[15]}$ Data were analyzed using MS Excel and Pabón Lasso diagram was obtained with SPSS 22 statistics software.

Table 1. Hospital bed performance indicators

\section{Indicators} Description

BOR Percentage of beds occupied by patients in a defined period of time

BTR

Refers to average number of inpatients per bed in the year

ALS
Formula

$\mathrm{BOR}=$ Inpatient days/bed days $\times 100$

Inpatient days $=$ Admissions $\times$ ALS

Bed days in year $=$ Number of beds $\times 365$

BTR $=$ Total patient admissions/number of beds

ALS = Inpatient days/admissions

BOR: Bed occupancy rate; BTR: Bed turnover rate; ALS: Average length of stay. 


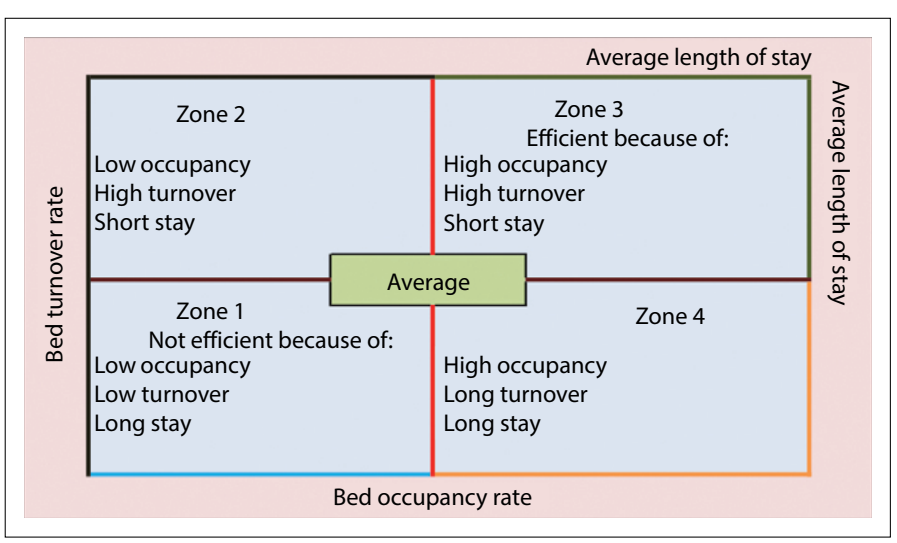

Figure 1. Pabon Lasso Model.

\section{Results}

In the scope of the study, bed, examination and inpatient information of pediatric clinics are given in Table 2. According to the research data, $77.1 \%, 10.5 \%$ and $12.4 \%$ of the patient beds belong to the departments of child health and diseases, pediatric surgery and other pediatrics, respectively. The highest number of examinations and number of inpatients were found to belong to child health and diseases and pediatric surgery clinics.

Hospital bed performance indicators of pediatrics departments which BOR, ALS, BRT findings are given in Table 3. According to the results obtained, bed performance indicators of pediatric clinics which BOR, BRT and ALS were found to be on average 46.2, 5.7 and 41.8, respectively. BOR was determined that highest in pediatric hematology and lowest in pediatric metabolic diseases department. ALS was found to be highest in child and adolescent mental health clinics and lowest in pediatric surgery department. BRT was found to be highest in pediatric surgery and lowest in pediatric metabolic diseases department.

As stated in the introduction of the research, PLM efficiently places clinics in the third region with high bed occupancy rates, high bed turnover rates and short long average stay. In this context, pediatric surgery, child urology, child health and diseases, pediatric hematology and oncology, pediatric endocrinology, pediatric chest diseases clinics were found to be efficient. With respect to the PLM, $38 \%$ of pediatric clinics were found to be fully productive.

In accordance with PLM, pediatric clinics which belong to low bed occupancy rate, low bed turnover rate and long patient stay are considered inefficient. As can be seen in Figure 2, pediatric metabolic diseases, child rheumatology, child neurology, pediatric gastroenterology, child nephrology, pediatric immunology and allergy diseases, pediatric cardiology clinics were located in the first region. However, it has been found that pediatric cardiology is very close to the efficiency limit. According to the PLM, $44 \%$ of the clinics were found to be completely inefficient. With respect to the model, the clinics in the fourth region have a long hospital stay, low bed turnover and high bed occupancy. As a result of the research, it was found that there were child and adolescent mental health and diseases, pediatric cardiovascular surgery, pediatric infectious diseases clinics in the fourth region. In accordance with the model, $18 \%$ of the clinics were in the fourth region and none of the pediatric clinics are located in the second region.

Table 2. Number of beds and patient of pediatrics departments in Turkey

\begin{tabular}{|c|c|c|c|c|c|c|}
\hline \multirow[t]{2}{*}{ Pediatrics departments } & \multicolumn{2}{|c|}{ Bed } & \multicolumn{2}{|c|}{ Physical examination } & \multicolumn{2}{|c|}{ Inpatient } \\
\hline & $\mathbf{n}$ & $\%$ & $\mathbf{n}$ & $\%$ & $\mathbf{n}$ & $\%$ \\
\hline Surgery & 1.675 & 10.5 & 1.591 .224 & 5.5 & 206.167 & 17.9 \\
\hline Endocrinology & 182 & 1.1 & 613.251 & 2.1 & 9.186 & 0.8 \\
\hline Infectious diseases & 282 & 1.8 & 121.324 & 0.4 & 8.558 & 0.7 \\
\hline Child and adolescent mental health & 196 & 1.2 & 1.211 .105 & 4.2 & 1.727 & 0.2 \\
\hline Gastroenterology & 128 & 0.8 & 334.651 & 1.2 & 4.448 & 0.4 \\
\hline Chest diseases & 13 & 0.1 & 45.080 & 0.2 & 530 & 0.0 \\
\hline Hematology and oncology & 415 & 2.6 & 356.885 & 1.2 & 22.435 & 2.0 \\
\hline Immunology and allergy & 100 & 0.6 & 502.215 & 1.7 & 3.797 & 0.3 \\
\hline Cardiovascular surgery & 102 & 0.6 & 3.971 & 0.0 & 1.523 & 0.1 \\
\hline Cardiology & 188 & 1.2 & 652.733 & 2.3 & 7.105 & 0.6 \\
\hline Metabolic diseases & 16 & 0.1 & 71.729 & 0.2 & 109 & 0.0 \\
\hline Nephrology & 170 & 1.1 & 424.363 & 1.5 & 4.558 & 0.4 \\
\hline Neurology & 128 & 0.8 & 522.942 & 1.8 & 3.180 & 0.3 \\
\hline Rheumatology & 40 & 0.3 & 64.581 & 0.2 & 842 & 0.1 \\
\hline Child health and diseases & 12.294 & 77.1 & 22.153 .494 & 77.2 & 873.973 & 76.0 \\
\hline Urology & 22 & 0.1 & 41.274 & 0.1 & 1.861 & 0.2 \\
\hline Total & 15.951 & 100.0 & 28.710 .822 & 100.0 & 1.149 .999 & 100.0 \\
\hline
\end{tabular}


Table 3. Hospital bed performance indicators of pediatrics departments in Turkey

\begin{tabular}{lccc} 
Pediatrics departments & BOR & ALS & BRT \\
\hline Surgery & 68.7 & 2.0 & 123.1 \\
Endocrinology & 50.2 & 3.6 & 50.5 \\
Infectious diseases & 61.2 & 7.4 & 30.3 \\
Child and adolescent mental & & & \\
health and diseases & 46.7 & 19.3 & 8.8 \\
Gastroenterology & 27.3 & 2.9 & 34.8 \\
Chest diseases & 60.3 & 5.4 & 40.8 \\
Hematology and oncology & 70.7 & 4.8 & 54.1 \\
Immunology and allergy diseases & 28.8 & 2.8 & 38.0 \\
Cardiovascular surgery & 54.5 & 13.3 & 14.9 \\
Cardiology & 42.0 & 4.1 & 37.8 \\
Metabolic diseases & 4.9 & 2.7 & 6.8 \\
Nephrology & 42.0 & 5.7 & 26.8 \\
Neurology & 32.5 & 4.8 & 24.8 \\
Rheumatology & 37.6 & 6.5 & 21.1 \\
Child health and diseases & 62.1 & 3.2 & 71.1 \\
Urology & 49.4 & 2.1 & 84.6 \\
Min. & 4.90 & 2.00 & 6.80 \\
Max. & 70.70 & 19.30 & 123.10 \\
Mean & 46.18 & 5.66 & 41.77 \\
SD & 17.4 & 4.56842 & 30.2432 \\
\hline
\end{tabular}

Min.: Minimum; Max.: Maximum; SD: Standard deviation; BOR: Bed occupancy rate; BTR: Bed turnover rate; ALS: Average length of stay.

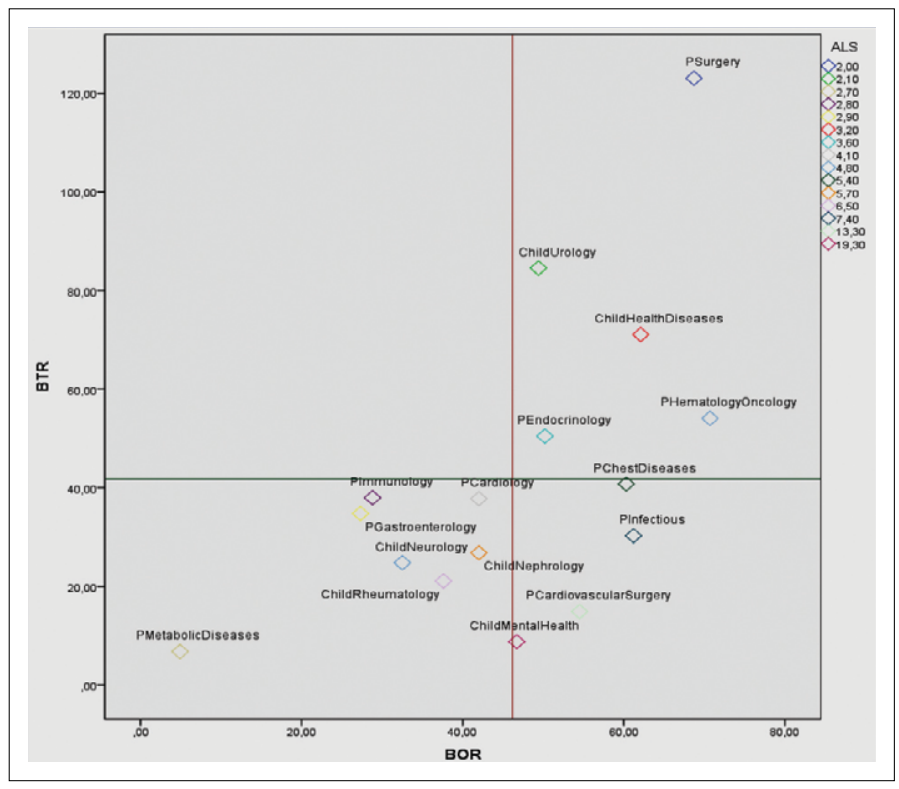

Figure 2. Location of the pediatric clinic in the Pabon Lasso Model.

\section{Discussion}

The department of pediatrics is a science that deals with the diagnosis, follow-up and treatment of individuals involved in the process from birth to adolescence. Pediatric clinics play an important role in the provision of health services. Therefore, the performance of pediatric clinics should be evaluated in order to provide more effective, quality and efficient health care services. The main reason for determining the performance levels of hospital clinics is to prevent waste of resources during the hospitalization process. ${ }^{[16]} \mathrm{A}$ significant portion of the cost in hospitals is due to poor management of patient bed. ${ }^{[17]}$

According to the results obtained, bed performance indicators of pediatric clinics which BOR, BRT and ALS were found to be on average 46.2, 5.7 and 41.8, respectively. Turkey Ministry of Health hospitals in general, according to data of 2017, It was determined as the average bed occupancy rate of $73.4 \%$, bed turnover rate of 56.2 (patient) and the average length of stay 4.5 days. ${ }^{[2]}$

There are many studies conducted with the PLM for evaluating bed performance in the health sector. PLM studies are mostly done by Iranian and Indian academics. As a common result of these researches, it was determined that the inter-regional cut-off points of the bed performance indicators were different in each survey. ${ }^{[3,4,11,18-26]}$

There are limited studies on this subject in Turkey. Some of these studies are presented below. In a study carried out by Yiğit and Esen with pabon lasso model and data envelopment analysis method, they determined the performance levels of the hospitals of Antalya Public Union. ${ }^{[27]}$ In a study conducted by Çalışkan, $25 \%$ of the hospitals found that they performed very well. In the study carried out by Yiğit, it was found that $23 \%$ of hospital clinics showed excellent performance and $18 \%$ had a very low performance level. ${ }^{[17]}$ Carried out by Yildı, it was found that there was a decrease in the average number of days of stay in the ministry of health and university hospitals between 2002-2015. ${ }^{[28]}$

\section{Conclusion}

One of the biggest problems of hospitals is the inefficient use of hospital beds. The utilization rate of hospital bed occupancy rate is around $70-80 \%$ in Turkey. Hospitals are able to determine whether they use patient beds efficiently by using hospital performance methods. The bed efficiency of hospitals has a significant impact on health system performance. Therefore, in order for pediatric clinics to provide quality and cost-effective health care, bed performance should be evaluated regularly. In addition to bed performance indicators, capacity utilization of personnel, buildings and equipment should be planned at the highest level. Potential improvements and strategies should be developed for idle capacity of pediatric clinics.

Conflict of interest: There are no relevant conflicts of interest to disclose.

\section{References}

1. Yiğit V, Yiğit A. Üniversite hastanelerinin finansal sürdürülebilir- 
liği. Mehmet Akif Ersoy Üniversitesi Sos Bilim Enstitüsü Derg 2016;8:253.

2. Sağlık Bakanlığı. Sağlık İstatistikleri Yıllığı 2017, Sağlık Bilgi Sistemleri Genel Müdürlüğü. Ankara: Kuban Matbaacılık Yayıncılık, 2018.

3. Aeenparast A, Farzadi F, Maftoon F. Quality of hospital bed performance studies based on pabon lasso model. Int J Hosp Res 2015;4:143-148.

4. Ajlouni MM, Zyoud A, Jaber B, et al. The relative efficiency of Jordanian Public Hospitals using data envelopment analysis and pabon lasso diagram. Glob J Bus Res 2013;7:59-73.

5. Bahadori M, Sadeghifar J, Hamouzadeh $P$, et al. Combining multiple indicators to assess hospital performance in Iran using the pabon lasso model. Australas Med J 2011;4:175-179.

6. Kavuncubaşı Ş, Ersoy K. Hastanelerde teknik verimlilik ölçümü. Amme İdaresi Derg 1995;28:77-92.

7. Hosseini SE, Ebrahimipour H, Badiee S, et al. Performance evaluation of Mashhad University of Medical Sciences ' hospitals during 2006-2011: Application of pabon lasso model. Jentashapir J Heal Res 2016;7:1-6.

8. Yiğit V, Ağırbaş İ. Hastane işletmelerinde kapasite kullanım oranının maliyetlere etkisi: Sağlık Bakanlığı Tokat Doğum ve Çocuk Bakımevi Hastanesinde Bir Uygulama. Hacettepe Sağlık İdaresi Derg 2004;7:141-162.

9. Ades $A E$, Lu G, Higgins JPT. The interpretation of random-effects meta-analysis in decision models. Med Decis Mak 2005;25:646654.

10. Goshtasebi A, Vahdaninia M, Gorgipour R, et al. Assessing hospital performance by the pabon lasso model. Iran J Public Health 2009;38:119-124.

11. Emamgholipour S, Afkar A, Eskandari M, et al. Performance evaluation of the effect of additive metformin to progesterone on patients a 5-year assessment with endometrial. Int J Hosp Res 2015;4:177-181.

12. Pabón Lasso H. Evaluating Hospital performance through simultaneous application of several indicators. Pan Am Heal Organ 1986;20:341-357.

13. Mehrtak M, Yusefzadeh $H$, Jaafaripooyan E. Pabon Lasso and Data envelopment analysis: a complementary approach to hospital performance measurement. Glob J Health Sci 2014;6:107-16.

14. Imamgholi S, Firouzabadi S, Goharinezhad S, et al. Assessing the efficiency of hospitals by using pabon lasso graphic model. J Res Heal 2014;4:890-897.

15. Sağlık Bakanlığı. Kamu Hastaneleri İstatistik Raporu, Kamu Has- taneleri Genel Müdürlüğü, İstatistik, Analiz, Raporlama ve Stratejik Yönetim Daire Başkanlığı. 2017.

16. Yiğit V. Hastanelerde teknik verimlilik analizi: Kamu hastane birliklerinde bir uygulama. SDÜ Sağlık Bilim Enstitüsü Derg 2016;7:916.

17. Yiğit V. Hastanelerde yatak kullanım etkinliğinin pabón lasso modeli ile analizi. Uluslararası Sağlık Yönetimi ve Strat Derg 2017;3:164-174.

18. Bahadori M, Sadeghifar J, Hamouzadeh P. Combining multiple indicators to assess hospital performance in Iran using the pabon lasso model. Australas Med J 2011;4:175-179.

19. Bastani $P$, Vatankhah S. Performance ratio analysis: $A$ national study on Iranian hospitals affiliated to ministry of Health and Medical Education. Iran J Public Health 2013;42:876-882.

20. Davoud A, Issac B, Sadeghi G, et al. Contemporary use of hospital efficiency indicators to evaluate hospital performance using the pabon lasso model. Eur J Bus Soc Sci 2014;3:1-8.

21. Gholami S, Sahraei Z, Khoshghadam M. Assessment of the Efficiency of Hospitals before and after the implementation of the health reform plan in Gazvin province based on the pabon lasso model (2011-2016). World Fam Med Journal/Middle East J Fam Med 2018;16:30-36.

22. Younsi M. Performance of Tunisian Public Hospitals: A Comparative assessment using pabon lasso model. Int J Hosp Res 2014;3:159-166.

23. Tripathi C, Kumar R, Sharma R. Assessment of performance of services in a tertiary care Neuropsychiatric Institute using pabon lasso model. Asian J Med 2016;7:69-74.

24. Moradi G, Piroozi B, Safari $H$, et al. Assessment of the efficiency of hospitals before and after the implementation of health sector evolution plan in Iran based on pabon lasso model. Iran J Public Health 2017;46:389-395.

25. Goshtasebi A, Vahdaninia M, Gorgipour R. Assessing hospital performance by the pabon lasso model. Iran J Public Health 2009;38:119-124.

26. Qodoosinejad J, Daemi A, Saadati M, et al. Evaluation of the efficiency of Tabriz hospitals; using the pabon lasso model in a 5-year period. Evid Based Heal Policy, Manag Econ 2017;1:151-157.

27. Yiğit V, Esen H. Pabon lasso modeli ve veri zarflama analizi ile hastanelerde performans ölçümü. SDÜ Sağlık Bilim Enstitüsü Derg 2017;8:26-32.

28. Yıldız MS. Türkiye'de 2002-2015 yılları arasında hastane yatak kullanımının değerlendirilmesi: pabon lasso metodu uygulaması. Hacettepe Sağlık İdaresi Derg 2017;20:347-356. 